IInnlegg på inntil $\mathbf{4 0 0}$ ord lastes opp i http://mc.manuscriptcentral.com/tidsskriftet.

Redaksjonen forbeholder seg retten til å foreta redaksjonelle endringer.

Forfattere av vitenskapelige artikler har tilsvarsrett (jf. Vancouver-gruppens regler).

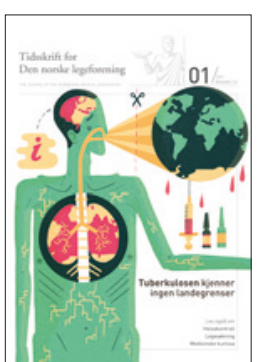

\section{Sakkyndighet i Høyesterett}

Lars Jacob Stovner er i et innlegg i Tidsskriftet nr. 1/2012 (1) uenig i min påstand i Tidsskriftet nr. 18/2011 (2) om at saken om nakkeskade ble ensidig belyst. For Høyesterett var det rettsoppnevnt to sakkyndige. Retten uttaler at det særlig er professor Stovner som viser til generell medisinsk forskning i sin sakkyndigerklæring. Jeg har gått gjennom hans erklæring for Høyesterett. Ved gjennomgang av Litauenstudiene nevnes ikke den omfattende vitenskapelige kritikken av studiene. Det er påfallende at Stovner neglisjerer flere studier som kritiserer Litauen-undersøkelsene (3). Jeg fastholder at den forskning som retten ble forelagt av den sakkyndige, synes å være ensidig. Fremstillingen i dommen av allment akseptert medisinsk viten blir ikke balansert.

Høyesterett og andre domstoler er helt avhengige av at en rettsoppnevnt sakkyndig utreder medisinsk kunnskap på en betryggende måte. I Lie-dommen (4) uttaler Høyesterett:

«... Det tredje forhold jeg vil trekke frem er at rettens behov for sakkyndighet må bli dekket på en betryggende måte. I saker med kompliserte og omtvistede medisinske årsaksforhold, sier det seg nærmest selv at det må oppnevnes medisinsk sakkyndige.»

«... Rettsoppnevnte sakkyndige vil gjerne med en større grundighet utrede de mer generelle og spesielle medisinske spørsmål saken reiser.»

Retten gir uttrykk for særskilt tillit til sakkyndige oppnevnt av retten. Det er retten som oppnevner spesialistene og gir mandat. De sakkyndige har derfor ingen binding til sakens parter, selv om partene gjerne foreslår sakkyndige.

De rettsoppnevnte sakkyndige bygger på oppdaterte dokumenter i saken og vil være til stede under hovedforhandlingen. Deres mandat bygger gjerne på at standardisert mandat, jf. Røsæg-utvalgets mandat, inntatt i Norges offentlige utredninger (5). Den rettsoppnevnte sakkyndige er rettens rådgiver i sakens medisinske spørsmål og forventes å utrede saken på en grundig og objektiv måte.

En rettsoppnevnt sakkyndig plikter å veilede retten om allment akseptert medisinsk viten. Den sakkyndige må i sin fremstilling sørge for at også kritikk av studier kommer tydelig frem. Det skal ikke være overlatt til prosessfullmektiger å fremlegge oversikter og studier som går $i$ en annen retning. Stovners innlegg illustrerer et hovedpoeng i min artikkel, nemlig at det er behov for en balansert fremstilling av hva som er allment akseptert medisinsk viten til enhver tid, samt viktigheten av at domstolene foretar en fordomsfri vurdering av bevisene i den enkelte sak.

Høyesterett fulgte i dommen vanlig praksis om å vurdere de fysiske skader ut fra de fire etablerte kriteriene. Dommen synes korrekt i resultatet ut fra skadelidtes uvanlige sykdomsforløp, men Høyesterett har bygd på ensidig medisinsk kunnskap.

\section{Stein Chr. Hexeberg}

sch@vogtwiig.no

Advokatfirmaet Vogt \& Wiig AS

Stein Chr. Hexeberg (f. 1953) er advokat med møterett for Høyesterett og partner

i advokatfirmaet Vogt \& Wiig. Hexeberg arbeider med personskadeerstatning, forsikring og prosedyre.

Ingen oppgitte interessekonflikter.

\section{Litteratur}

1. Stovner LJ. Høyesterettsdommen er korrekt. Tidsskr Nor Legeforen 2012; 132: 11-2.

2. Hexeberg SC. Ny Høyesterettsdom om nakkeskade. Tidsskr Nor Legeforen 2011; 131: 1804-5.

3. Nakkeslengskade. Diagnostikk og evaluering. SMM-rapport nr. 5/2000. Oslo: Senter for medisinsk metodevurdering, 2000. www.kunnskapssenteret.no/Publikasjoner/ attachment/11054?=true\&_ts $=12 \mathrm{cc} 5 \mathrm{f0} 3 \mathrm{e} 26$ (16.5.2011).

4. Norsk Retstidende. Oslo: Den Norske Advokatforening, 1998: 1565.

5. Norges offentlige utredninger. Forsikringsselskapers innhenting, bruk og lagring av helseopplysninger. NOU 2000: 23.

\section{Om teologi og teleologi}

Vi ser til vår fryd at vår bok Etikk - teori og praksis, utgitt på Cappelen Damm Akademisk $\mathrm{i}$ juni $\mathrm{i}$ fjor, får positiv omtale $\mathrm{i}$ Tidsskriftet nr. 2/2012 (1). Det gleder oss stort at anmelderen har funnet den både over- siktlig og interessant. Anmelderen har tydeligvis lest både godt og grundig, noe som også reflekteres $i$ at han har oppdaget et par pinlige feil. At helsedirektøren får etternavnet Hansen i stedet for Larsen (s. 158), er en beklagelig miss som forfatterne fullt og helt tar på sin kappe. Vi har tidligere rødmet da en kollega gjorde oss oppmerksomme på at den nasjonale forskningsetiske komité for medisin og helsefag (NEM) på side 190 står omtalt som «Den nasjonale forskningsetiske komité for medisinsk og helsefaglig forskning». Hastverk er som kjent lastverk.

Lettere sjokkert ble vi imidlertid først ved å lese at vi «blander sammen teologisk og teleologisk etikk». Etter å ha bladd oss gjennom boken, oppdaget vi imidlertid synderen, nemlig en trykkfeil i tabellen på side 197. Dette skyldes nok en overivrig korrekturleser - vi kan forsikre om at denne feilen ikke forekom i vårt manus, selv om vi burde ha oppdaget den ved siste gjennomgang av korrekturen. Vi ber om å få presisere dette, slik at det ikke fremstår slik at forfatterne ikke kan forskjell på teologi og teleologi, noe som kunne kvalifisere til strykkarakter på examen philosophicum. Vi satser på at mange følger anmelderens oppfordring om å lese vår innføring i etikk, slik at førsteopplaget går raskt unna og vi får anledning til å rette opp disse feilene i neste utgave.

\section{Siri Granum Carson}

Trondheim

\section{Norunn Korsberg}

Oslo

Siri Granum Carson (f. 1972) har en ph.d. i filosofi og er førsteamanuensis på program for anvendt etikk ved Norges teknisk-naturvitenskapelige universitet. Ingen oppgitte interessekonflikter.

Norunn Kosberg (f. 1970) har hovedfag i filosofi med etikk og menneskerettigheter som spesialfelt. Hun har flere års undervisningserfaring innenfor etikk og filosofi.

Ingen oppgitte interessekonflikter.

\section{Litteratur}

1. Hytten K. Oversiktlig innføring i etisk teori og praksis. Anmeldelse av: Carson SG, Korsberg N. Etikk. Tidsskr Nor Legeforen 2012; 132: 184. 